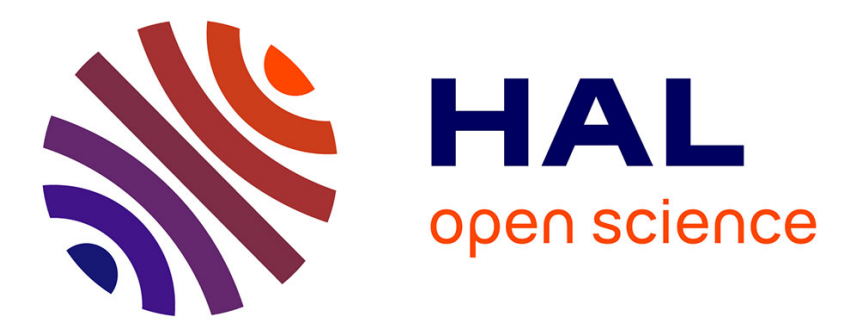

\title{
Lipid Classes, Fatty Acids, Tocopherols Compositions and Antioxidant Activity of Lawsonia alba Seed Oils Growing in Algeria
}

Rekia Cherbi, Chahrazed Hamia, Nadhir Gourine, Isabelle Bombarda, Mokhtar Saïdi, Mohamed Yousfi

\section{To cite this version:}

Rekia Cherbi, Chahrazed Hamia, Nadhir Gourine, Isabelle Bombarda, Mokhtar Saïdi, et al.. Lipid Classes, Fatty Acids, Tocopherols Compositions and Antioxidant Activity of Lawsonia alba Seed Oils Growing in Algeria. Current Nutrition and Food Science, 2017, 13 (2), pp.121 - 130. 10.2174/1573401313666161125144545 . hal-01777684

\section{HAL Id: hal-01777684 \\ https://hal.science/hal-01777684}

Submitted on 25 Apr 2018

HAL is a multi-disciplinary open access archive for the deposit and dissemination of scientific research documents, whether they are published or not. The documents may come from teaching and research institutions in France or abroad, or from public or private research centers.
L'archive ouverte pluridisciplinaire HAL, est destinée au dépôt et à la diffusion de documents scientifiques de niveau recherche, publiés ou non, émanant des établissements d'enseignement et de recherche français ou étrangers, des laboratoires publics ou privés. 


\title{
Lipid Classes, Fatty Acids, Tocopherols Compositions and Antioxidant Activity of Lawsonia alba Seed Oils Growing in Algeria
}

\author{
Rekia Cherbi $^{\mathrm{a}}$, Chahrazed Hamia ${ }^{\mathrm{b}}$, Nadhir Gourine ${ }^{\mathrm{b}}$, Isabelle Bombarda ${ }^{\mathrm{c}}$, Mokhtar Saïdi ${ }^{\mathrm{a}}$ and \\ Mohamed Yousfi, ${ }^{\text {,* }}$
} ${ }^{a}$ Laboratoire de Valorisation et Promotion des Ressources Sahariennes (LVPRS), Faculté des Mathématiques et des
Sciences de la Matière, Université de Ouargla BP. 511, route de Ghardaïa (30000) Ouargla, Algeria; ${ }^{b}$ Laboratoire des
Sciences Fondamentales (LSF), Université Amar Télidji, Laghouat, BP. 37G, (03000) Laghouat, Algeria; ${ }^{c}$ Laboratoire
d'Instrumentation et de Sciences Analytiques (LISA), Équipe Méthodologie, Traitement de l'Information en Chimie Ana-
lytique (METICA), EA 4672, Université Aix-Marseille, Marseille, France

\begin{abstract}
Background: Lawsonia alba seed oils are not widely used commercially even though they have characteristics that well suit for industrial applications and can contribute to healthy human diets. The most important aim of the present work is the evaluation of the tocopherols composition of these oils. Moreover, lipid classes, fatty acids compositions and antioxidant activity of the seed oils were also investigated.

Methods: Lawsonia alba seed oils were extracted with Soxhlet device using $n$-hexane and chloroform/methanol. Tocopherols were analyzed by HPLC The antioxidant activity were determined using two different assays: DPPH (1,1-diphenyl-2-picrylhydrazyl), and Phosphomolybdenum.

Results: The content of the oils ranged from 7.52 to $10.45 \%$. Polyunsaturated fatty acids dominated all the studied samples. Linoleic, followed by palmitic and oleic, were the major fatty acids found in the crude seed oils and their lipid classes. Results of tocopherols identification showed that the seed oils were rich in tocopherols, especially $\gamma$ - and $\delta$ - tocopherols. For DPPH assay, the antioxidant powers varied from medium to low values $\left(\mathrm{IC}_{50}=0.11\right.$ to $16.54 \mathrm{mg} / \mathrm{mL}$ ). The results of the Phosphomolybdenum assay showed very important activities of the oils that were decreasing in the following order: polar lipids > neutral lipids (Chloroform/Methanol) $>$ total lipids $>$ neutral lipids (n-hexane).

Conclusion: this current report reveals the richness of the Lawsonia alba seeds in tocopherols, which in fact is studied for the first time. Moreover, cluster analysis revealed that fatty acid composition of the seed oils of Lawsonia alba were very close to those of Walnut.
\end{abstract}

Keywords: Lawsonia alba, seeds, lipids, fatty acids, tocopherols, DPPH assay, Phosphomolybdenum assay, Hierarchy Ascendant Classification (HAC).

\section{INTRODUCTION}

Lawsonia alba (syn. Lawsonia inermis Linn.) locally known as El-Henna is (Henna) is a plant from the Lythraceae. It is native to North Africa and South East Asia, and is often cultivated as an ornamental plant throughout India, Persia, and along the African coast of the Mediterranean Sea [1-5]. It is a unique source of various pharmacologically important compounds such as naphthoquinone (Lawsone) derivatives, aliphatic components, triterpenes, sterols, essential oils, phenolic derivatives, fatty acids, amino acids, coumarins, xanthones, flavonoids and other constituents [6, 7]. Lawsonia alba is known to contain antibacterial [6], antifungal [8], antiparasitic [9], antiviral [10], anticancer [11], antidiabetic $[12,13]$, antioxidant $[14,15]$, tuberculostatic [16], anti-inflammatory [17], antifertility [18] and wound healing properties [19]. Only a few works on the chemical composition of the fatty acids of the seed oils of Lawsonia alba have been reported [20-24]. Lawsonia alba seed oils are not widely used commercially even though they have characteristics that well suit for industrial applications and can contribute to healthy human diets.

To our knowledge, no report has been found on the evaluation of the composition of the tocopherols of Lawsonia alba seeds grown in Algeria, nor on their antioxidant activities. 


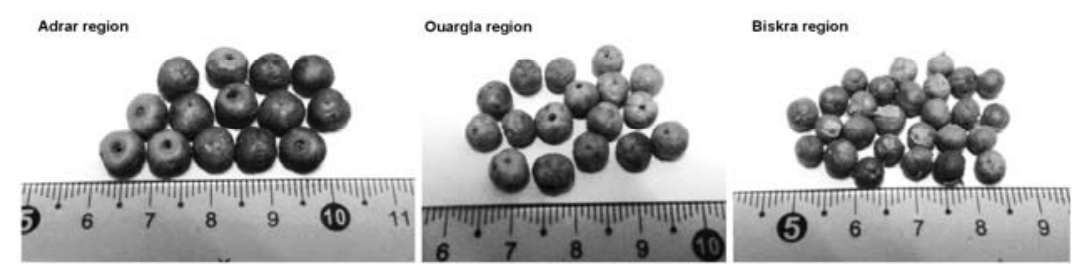

Fig. (1). Seeds of Lawsonia. alba from different regions in Algeria.

\section{MATERIALS AND METHODS}

\section{Chemicals}

Methanol, chloroform, 2-propanol, absolute ethanol, sulfuric acid, anhydrous sodium sulphate, sodium chloride, silica gel $(60 \mathrm{G})$, sodium, ascorbic acid, sodium thiosulfate, potassium hydroxide, ammonium molybdate, sodium phosphate were purchased from Merck, Germany. $n$-hexane, butylated hydroxytoluene (BHT), butylated hydroxyanisole (BHA), $\alpha$-tocopherol (Vitamin E), DPPH ${ }^{*}$ (1,1-diphenyl,2picrylhydrazyl) were obtained from Sigma-Aldrich Chemical Co. USA. All reagents and chemicals used were of analytical grade.

\section{Collection of Plant Material}

The seeds of Lawsonia alba samples used in this study were collected during the maturation stage in October 2011, from three different locations (Adrar, Ouargla and Biskra), located in the south of Algeria. The sizes of the seeds were $7.0 \pm 0.3 \mathrm{~mm}, 5.0 \pm 0.3 \mathrm{~mm}$ and $4.0 \pm 0.3 \mathrm{~mm}$ for Adrar, Ouargla and Biskra regions, respectively (Fig. 1).

\section{Oil Extraction}

The oil was extracted from seeds using $n$-hexane solvent. The dried grounded seeds of $L$. alba $(100 \mathrm{~g})$ were extracted with $300 \mathrm{~mL} n$-hexane using a soxhlet extraction apparatus for $24 \mathrm{~h}$. The $n$-hexane was evaporated in a rotary vacuum evaporator at $40^{\circ} \mathrm{C}$.

\section{Extraction of Total Lipids from L. alba}

The total lipids were extracted by the method of Folch et al [25]. The seeds used in this study were dried under the shade, ground in a coffee grinder to fine powder and weighed accurately; about $100 \mathrm{~g}$ of the powder was extracted in $400 \mathrm{~mL}$ of chloroform/methanol $(2: 1, \mathrm{v} / \mathrm{v})$ for 24 hours using Soxhlet apparatus (extractor). The solvent was evaporated in a rotary vacuum apparatus at $40{ }^{\circ} \mathrm{C}$. The residue was dissolved in $200 \mathrm{~mL}$ of aqueous sodium chloride (9\%), then $200 \mathrm{~mL}$ of chloroform was added and the phases were mixed vigorously. After phase separation, the chloroform layer was withdrawn, dried over anhydrous sodium sulphate $\mathrm{Na}_{2} \mathrm{SO}_{4}$ and filtered. The filtrate was then concentrated under vacuum. The extracted lipids were weighed to determine the total lipids content, and then stored at $+4{ }^{\circ} \mathrm{C}$ for further analysis.

\section{Isolation of Neutral Lipids, Polar Lipids by Column Chromatography}

The extracted lipids $(2 \mathrm{~g})$ were separated into Neutral Lipids (NLs) and polar lipids Glycolipids (GLs) and Phospholipids (PLs) by column chromatography with $10 \mathrm{~g}$ of activated silica gel $(60 \mathrm{G})$. Neutral lipids and polar lipids were eluted successively using chloroform and methanol, respectively. The individual fractions were evaporated under vacuum to remove solvent and the weight of each lipid class was expressed as a percentage of the total lipid dry weight.

\section{Fatty Acid (FA) Composition}

The FA composition of the oils was determined after having converted the FA into FA Methyl Esters (FAMEs) then analysed by Gas Chromatography (GC). The methyl esters were prepared by the following procedure: Oils $(50$ $\mathrm{mg}$ ) were refluxed for $30 \mathrm{~min}$ in $20 \mathrm{~mL}$ of $1 \%$ sodium methylate $(\mathrm{NaOMe})$, and then $20 \mathrm{~mL}$ of water was added. The Fatty Acid Methyl Esters (FAMEs) were extracted by $n$ hexane and washed with distilled water. The combined extracts were dried over anhydrous sodium sulphate $\mathrm{Na}_{2} \mathrm{SO}_{4}$ and evaporated under vacuum, then analysed by capillary gas chromatography.

\section{Chromatographic Analysis of FAME(s)}

A gas chromatographic GC (model Chrompack CP 9002) was equipped with a FID detector and DB-23 capillary column $(30 \mathrm{~m} \times 0.32 \mathrm{~mm}$ internal diameter, $0.25 \mu \mathrm{m}$ film thickness). Two $\mu \mathrm{L}$ of the sample was injected in the Split injection mode. The oven analysis temperature started at $200{ }^{\circ} \mathrm{C}$ for $10 \mathrm{~min}$ and was raised at a rate of $4{ }^{\circ} \mathrm{C} / \mathrm{min}$ to $250{ }^{\circ} \mathrm{C}$. The injector temperature was $250{ }^{\circ} \mathrm{C}$ and the detector temperature was $280{ }^{\circ} \mathrm{C}$, the flow rate of nitrogen (carrier gas) was $1 \mathrm{~mL} / \mathrm{min}$. Identification and quantification of FAMEs were accomplished by comparing the retention times of peaks with those of pure standards purchased from Sigma and analysed under the same conditions. The results were expressed as total area percentage of identified individual fatty acids in the lipid fraction.

\section{Tocopherol Analysis}

Prior to HPLC analysis, $35 \mathrm{mg}$ of seed oil extracted with $n$-hexane was diluted with $1 \mathrm{~mL}$ of $n$-hexane, and then $20 \mu \mathrm{L}$ of the solution was injected. Tocopherols were analyzed by HPLC using an Agilent 1290 Infinity apparatus equipped with a Quaternary Pump Model 1260, an automatic liquid sample and a Fluorimetric Detector (FLD 1260). The detection was set at $295 \mathrm{~nm}$ for excitation wavelength and at 330 $\mathrm{nm}$ for emission wavelength. The separation column was a SI60 $(250 \mathrm{~mm} \times 4.6 \mathrm{~mm}$ i.d., $5 \mu \mathrm{m}$, Lichrosorb, Merck KGaA Darmstadt, Germany). The mobile phase was $n$ hexane/isopropanol, 99/1, v/v, in isocratic mode, with a flow rate set at $1 \mathrm{~mL} / \mathrm{min}$, during $20 \mathrm{~min}$. Column compartment was set at $25^{\circ} \mathrm{C}$. Commercial standard $(\alpha$-Toc) and a mixture $(\alpha$-Toc, $\beta$-Toc, $\gamma$-Toc and $\delta$-Toc) were co-injected with samples for the identification of tocopherol isomers.

\section{Chemical Analysis}

Refractive Index (RI), Acid Value (AV), Iodine Value (IV), Saponification Value (SV) and ester Value (EV) of the 
extracted Lawsonia alba seed oils were determined according to the standard methods of the French Association of Normalisation "Association Française de Normalisation', AFNOR NF T 60-206, 1984) [26]. All experiments were performed in triplicate.

\section{Radical-Scavenging Activity (DPPH Assay)}

The antioxidant activity was determined by DPPH method, which is based on the evaluation of the free-radical scavenging capacity. In this method, the 1,1 diphenyl-2picrylhydrazyl $\left(\mathrm{DPPH}^{\circ}\right)$ free stable radical was used to measure the antioxidant activity. Briefly, $1 \mathrm{~mL}$ of the sample diluted in ethanol or 2-propanol was mixed with $1 \mathrm{~mL}$ of $0.25 \mathrm{mM} \mathrm{DPPH}^{\circ}$ in ethanol. The reaction mixture was well shaken and incubated in the dark at room temperature for a time period of $30 \mathrm{~min}$. The absorbance of the resulting solution was read at $517 \mathrm{~nm}$ against a blank [27]. The antiradical activity was expressed as $\mathrm{IC}_{50}(\mathrm{mg} / \mathrm{mL})$ : the concentration required to cause $50 \%$ initial $\mathrm{DPPH}^{\circ}$ inhibition. The inhibitory percentage of $\mathrm{DPPH}^{*}$ was calculated according to the following equation:

IC "Scavenging activity $\% "=\left[1-\left(\mathrm{A} / \mathrm{A}_{0}\right)\right] \times 100$.

Where A: Absorbance of the sample; $A_{0}$ : Absorbance of the control (Initial value)

All experiments were performed in triplicate.

\section{Total Antioxidant Activity (Phosphomolybdenum Assay)}

The total antioxidant activity of the samples was determined by the phosphomolybdenum method PPM of Prieto et al. [28]. Briefly, $0.3 \mathrm{~mL}$ of oil extract dissolved in ethanol or 2-propanol was mixed with $3 \mathrm{~mL}$ of the reagent solution $(0.6 \mathrm{~mol} / \mathrm{L}$ sulphuric acid, $28 \mathrm{mmol} / \mathrm{L}$ sodium phosphate and $4 \mathrm{mmol} / \mathrm{L}$ ammonium molybdate). The tubes were capped and incubated in a water bath at $95{ }^{\circ} \mathrm{C}$ for 90 min. The tubes were cooled to room temperature and the absorbance of the green phosphomolybdenum complex was measured at $695 \mathrm{~nm}$. In the case of the blank, $0.3 \mathrm{~mL}$ of solvent was used in place of the sample (oil). Ascorbic acid was used as a standard. Total antioxidant capacity was expressed as equivalents of vitamin E: VEAEC= "Vitamin E Equivalent Antioxidant Capacity"). All experiments were performed in triplicate.

\section{Cluster Analysis}

Cluster analysis was performed using hierarchical clustering (Ward's technique) with Euclidean distance measure. The calculus was performed using a set of data composed of 9 different plants (representing 18 individuals) and 14 variables (fatty acids: $\mathrm{C}_{10: 0}, \mathrm{C}_{12: 0}, \mathrm{C}_{14: 0}, \mathrm{C}_{16: 0}, \mathrm{C}_{16: 1}, \mathrm{C}_{17: 0}, \mathrm{C}_{17: 1}$, $\mathrm{C}_{18: 0}, \mathrm{C}_{18: 1}, \mathrm{C}_{18: 2}, \mathrm{C}_{18: 3}, \mathrm{C}_{20: 0}, \mathrm{C}_{20: 1}, \mathrm{C}_{20: 5}$ ).

\section{RESULTS AND DISCUSSION}

\section{Physico-Chemical Properties}

The oils of Lawsonia alba seeds from the three different regions in Algeria (Adrar, Biskra, and Ouargla) were Soxhlet extracted with chloroform/methanol 2:1, v/v) and with $n$ hexane. The oils (total lipids) content is summarized in Tables 1 and 2 . The results showed that the yields of extraction obtained with chloroform/methanol solvent were slightly higher than those obtained with $n$-hexane. Moreover, the values of the yields were practically the same for the three studied regions. In fact, the yield values were in the range of $7.52-9.56 \% \mathrm{w} / \mathrm{w}$ for the $n$-hexane solvent extraction; and were in the range of $9.88-10.45 \% \mathrm{w} / \mathrm{w}$ when the chloroform/methanol solvent was used. As a result, the nature of solvent did not strongly affect the extraction yield. Furthermore, the crude lipid contents obtained by the two solvents revealed that these seeds cannot be considered as oil-bearing: since their oil contents were low and were in the range of some other vegetable materials such as wheat germ, acorns (Quercus sp), Pistacia lentiscus, Sorghom, Hippophae rhamnoides, Myrtus communis and Rhanterium adpressum flowers [29-33]. The yields found here in this investigation are in very good agreement with those of literature (India and USA): 7.5\% "hexane extract" [34], and 9.6\% "pentane extract" [35]. On the other hand, these seed oil contents are important compared to other seed oils such as corn (3.0-6.5\%) [36]. In addition, the slight difference in the yields may be due to the different origins of the seeds as well as the different environmental conditions that affect lipid development [37].

The results of the physico-chemical characteristics of the oils are presented in Tables $\mathbf{1}$ and 2 . All the oils had a pleasant odour and a dark green colour, while the colour of the oil extracted by chloroform/methanol (Ouargla) was brown. These colours indicate the presence of chlorophylls and various carotenoids pigments [38, 39]. The seed oil states at room temperature $\left(25.0 \pm 1{ }^{\circ} \mathrm{C}\right)$ were generally in the form of semi liquids. However, the oils from Adrar were liquid for both solvents.

The refractive indexes of the six investigated neutral lipid extracts were found to be pretty similar. The results also indicated that these oils presented high unsaturation bonds. The greater the degree of unsaturation, the higher refractive index will be [37]; this relationship was confirmed by the values of fatty acid composition of the oils presented in Tables $\mathbf{1}$ and $\mathbf{2}$.

The acid value is a measure of the total acidity of the lipid [40]. The acid values of L. alba seed oils from Biskra, extracted by $n$-hexane and $\mathrm{CHCl}_{3} / \mathrm{MeOH}$ were very high: 169.47 and 146.59 " $\mathrm{mg} \mathrm{KOH} / \mathrm{g}$ oil", respectively, while, the Acid Values (AVs) of $L$. alba seed oils from the rest of the regions (Adrar and Ouargla) varied form weak to low values 4.39-43.36 "mg KOH/g oil". The weakest value of AV was recorded for the region of Adrar when $n$-hexane solvent was used. These results can be attributed to the action of lipolytic enzymes [37], the bad conservation of the seeds before extraction [29], or the incomplete ripeness of the seeds.

The saponification value (SV) is a measure of the fatty acids molecular weight, and defined as the amount of alkali required to saponify fatty acids in a given weight of oil [41]. The saponification values of the oils prepared by $\mathrm{Ch} / \mathrm{MeOH}$ were higher than those of the oils extracted by $n$-hexane. This indicates that the oils achieved by $\mathrm{Ch} / \mathrm{MeOH}$ contain high amounts of low molecular weight of fatty acids [37], because a high saponification value indicates very high content of low molecular weight triacylglycerols [42]. This value makes them useful in the production of liquid soaps and shampoos $[43,44]$. 
Table 1. Physicochemical proprieties and fatty acid compositions of Lawsonia alba seed oils (n-hexane solvent).

\begin{tabular}{|c|c|c|c|}
\hline \multirow{2}{*}{ Fatty Acids } & \multicolumn{3}{|c|}{ Composition (\%) } \\
\hline & Biskra & Ouargla & Adrar \\
\hline \multicolumn{4}{|l|}{ Saturated } \\
\hline C14:0 & $\operatorname{tr}$ & $\operatorname{tr}$ & $\operatorname{tr}$ \\
\hline C16:0 & $9.65 \pm 0.51$ & $8.74 \pm 0.47$ & $10.69 \pm 0.49$ \\
\hline C17:0 & $0.10 \pm 0.05$ & $0.10 \pm 0.06$ & $0.10 \pm 0.04$ \\
\hline C18:0 & $3.72 \pm 0.08$ & $3.86 \pm 0.09$ & $3.29 \pm 0.07$ \\
\hline C20:0 & $1.86 \pm 0.06$ & $1.68 \pm 0.04$ & $1.39 \pm 0.05$ \\
\hline \multicolumn{4}{|l|}{ Monoinsaturated } \\
\hline C16:1 & $0.09 \pm 0.02$ & $0.10 \pm 0.04$ & $0.10 \pm 0.04$ \\
\hline $\mathrm{C} 17: 1$ & $\operatorname{tr}$ & $\operatorname{tr}$ & $\operatorname{tr}$ \\
\hline C18:1 & $10.98 \pm 0.23$ & $10.19 \pm 0.19$ & $8.62 \pm 0.11$ \\
\hline C20:1 & $0.41 \pm 0.02$ & $0.38 \pm 0.03$ & $0.32 \pm 0.03$ \\
\hline \multicolumn{4}{|l|}{ Polyinsaturated } \\
\hline $\mathrm{C} 18: 2$ & $71.71 \pm 0.08$ & $74.06 \pm 0.09$ & $74.39 \pm 0.07$ \\
\hline $\mathrm{C} 18: 3$ & $0.37 \pm 0.03$ & $0.25 \pm 0.03$ & $0.20 \pm 0.02$ \\
\hline C20:5 & $0.53 \pm 0.04$ & $0.60 \pm 0.05$ & $0.47 \pm 0.04$ \\
\hline SAFA & 15.33 & 14.38 & 15.47 \\
\hline MUFA & 11.48 & 10.67 & 09.04 \\
\hline PUFA & 72.61 & 74.91 & 75.06 \\
\hline Total & 99.42 & 99.96 & 99.57 \\
\hline $\mathrm{U} / \mathrm{S}$ & 5.48 & 5.95 & 5.43 \\
\hline Yield \% “w/w" & $9.56 \pm 0.57$ & $7.52 \pm 0.63$ & $8.26 \pm 0.71$ \\
\hline Acid value (AV) “mg KOH/g oil” & $169.47 \pm 1.48$ & $12.67 \pm 0.29$ & $4.39 \pm 0.03$ \\
\hline Saponification value (SV) “mg KOH/g oil”" & $193.87 \pm 0.45$ & $222.70 \pm 0.6$ & $183.20 \pm 0.32$ \\
\hline Iodine value (IV) "mg iodine/100g oil" & $68.00 \pm 0.73$ & $110.92 \pm 1.26$ & $108.88 \pm 1.03$ \\
\hline Refraction Index (RI) & $1.4808 \pm 0.0007$ & $1.4799 \pm 0.0005$ & $1.4780 \pm 0.0009$ \\
\hline
\end{tabular}

tr: traces

The iodine value is used to assess the unsaturation of the oils and in assessing the stability of oils in industrial applications [45]. The range of iodine numbers were 68.0113.3 "mg/100g oil", thus, the $L$. alba seed oil could be classified as a non-drying oil. The high iodine value is due to the high content of unsaturated fatty acids of a sample. For both solvents, the highest IVs were recorded for Adrar oils, and the lowest ones were observed for the Biskra region.

\section{Lipid Classes and Fatty Acid Composition of L. alba Seed Oil and Its Lipid Classes}

After quantification of the lipid classes, it was noted that neutral and polar lipids were absent (not detected) in the total lipids obtained by $n$-hexane solvent. In the opposite side, when chloroform/methanol solvent was used, the content of neutral lipids was very significant (85.82-93.08\%), and the 
Table 2. Physicochemical proprieties and fatty acid compositions of Lawsonia alba seed oils (Chloroform/Methanol solvent extraction and fractionations).

\begin{tabular}{|c|c|c|c|c|c|c|c|c|c|}
\hline \multirow{3}{*}{ Fatty Acids } & \multicolumn{9}{|c|}{ Composition (\%) } \\
\hline & \multicolumn{3}{|c|}{ Total Lipids Extraction } & \multicolumn{3}{|c|}{ Neutral Lipids Sub-Extraction } & \multicolumn{3}{|c|}{ Polar Lipids Sub-Extraction } \\
\hline & Biskra & Ouargla & Adrar & Biskra & Ouargla & Adrar & Biskra & Ouargla & Adrar \\
\hline \multicolumn{10}{|l|}{ Saturated } \\
\hline C14:0 & $0.40 \pm 0.02$ & $\operatorname{tr}$ & $0.04 \pm 0.02$ & $\operatorname{tr}$ & $\operatorname{tr}$ & $0.04 \pm 0.02$ & $0.52 \pm 0.02$ & $0.27 \pm 0.02$ & - \\
\hline $\mathrm{C} 16: 0$ & $12.93 \pm 0.49$ & $8.76 \pm 0.35$ & $11.04 \pm 0.15$ & $12.05 \pm 0.21$ & $8.84 \pm 0.29$ & $11.27 \pm 0.27$ & $15.43 \pm 0.43$ & $21.52 \pm 0.48$ & $15.56 \pm 0.37$ \\
\hline C17:0 & $0.56 \pm 0.06$ & $\operatorname{tr}$ & $0.11 \pm 0.02$ & $\operatorname{tr}$ & $\operatorname{tr}$ & $0.11 \pm 0.02$ & - & $0.69 \pm 0.04$ & - \\
\hline C18:0 & $5.04 \pm 0.11$ & $4.10 \pm 0.13$ & $3.68 \pm 0.15$ & $4.80 \pm 0.14$ & $4.03 \pm 0.11$ & $3.51 \pm 0.16$ & $5.15 \pm 0.17$ & $8.01 \pm 0.21$ & $5.41 \pm 0.12$ \\
\hline C20:0 & $2.33 \pm 0.03$ & $1.82 \pm 0.02$ & $1.70 \pm 0.02$ & $2.26 \pm 0.05$ & $1.82 \pm 0.04$ & $1.52 \pm 0.03$ & $1.91 \pm 0.02$ & $2.48 \pm 0.03$ & - \\
\hline \multicolumn{10}{|l|}{ Monoinsaturated } \\
\hline C16:1 & - & - & - & $0.22 \pm 0.02$ & $0.12 \pm 0.01$ & $0.08 \pm 0.01$ & - & - & - \\
\hline C17:1 & - & - & - & $\operatorname{tr}$ & - & $0.03 \pm 0.01$ & - & - & - \\
\hline C18:1 & $11.12 \pm 0.34$ & $10.55 \pm 0.46$ & $8.66 \pm 0.34$ & $11.31 \pm 0.31$ & $10.38 \pm 0.37$ & $8.48 \pm 0.38$ & $11.60 \pm 0.32$ & $17.19 \pm 0.33$ & $15.04 \pm 0.30$ \\
\hline C20:1 & $0.40 \pm 0.02$ & $0.36 \pm 0.03$ & $0.35 \pm 0.02$ & $0.48 \pm 0.02$ & $0.41 \pm 0.02$ & - & $\operatorname{tr}$ & $0.61 \pm 0.03$ & - \\
\hline \multicolumn{10}{|l|}{ Polyinsaturated } \\
\hline C18:2 & $65.14 \pm 0.41$ & $73.14 \pm 0.49$ & $73.10 \pm 0.42$ & $67.72 \pm 0.45$ & $73.37 \pm 0.40$ & $73.68 \pm 0.43$ & $63.03 \pm 0.41$ & $45.10 \pm 0.40$ & $63.99 \pm 0.38$ \\
\hline C18:3 & $0.45 \pm 0.08$ & $0.45 \pm 0.07$ & $0.28 \pm 0.04$ & $0.30 \pm 0.05$ & $0.24 \pm 0.07$ & $0.27 \pm 0.06$ & $1.22 \pm 0.12$ & $0.69 \pm 0.15$ & - \\
\hline C20:5 & $0.77 \pm 0.19$ & $0.69 \pm 0.28$ & $0.69 \pm 0.23$ & $0.82 \pm 0.21$ & $0.73 \pm 0.24$ & - & $1.10 \pm 0.33$ & $2.43 \pm 0.31$ & - \\
\hline SAFA & 21.26 & 14.68 & 16.57 & 19.11 & 14.69 & 16.45 & 23.01 & 32.97 & 20.97 \\
\hline MUFA & 11.52 & 10.91 & 9.01 & 12.01 & 10.91 & 08.59 & 11.60 & 17.80 & 15.04 \\
\hline PUFA & 66.36 & 74.28 & 74.07 & 68.84 & 74.34 & 73.95 & 65.35 & 48.22 & 63.99 \\
\hline Total & 99.14 & 99.87 & 99.65 & 99.96 & 99.94 & 98.99 & 99.96 & 98.99 & 100.00 \\
\hline $\mathrm{U} / \mathrm{S}$ & 3.66 & 5.80 & 5.02 & 4.23 & 5.80 & 5.01 & 3.34 & 2.00 & 3.77 \\
\hline Yield \% "w/w" & $10.45 \pm 0.13$ & $9.88 \pm 0.31$ & $9.98 \pm 0.76$ & - & - & - & - & - & - \\
\hline Neutral lipids \% & - & - & - & $85.82 \pm 0.90$ & $87.85 \pm 0.67$ & $93.08 \pm 0.7$ & - & - & - \\
\hline Polar lipids \% & - & - & - & - & - & - & $13.85 \pm 0.80$ & $10.34 \pm 0.75$ & $3.90 \pm 0.52$ \\
\hline $\begin{array}{l}\text { Acid value (AV) "mg } \\
\text { KOH/g oil" }\end{array}$ & & & & $148.09 \pm 1.28$ & $43.36 \pm 0.65$ & $30.9 \pm 0.15$ & & & \\
\hline $\begin{array}{l}\text { Saponification value } \\
\text { (SV) “mg KOH/g oil" }\end{array}$ & & & & $216.42 \pm 0.56$ & $230.32 \pm 0.88$ & $205.73 \pm 0.20$ & & & \\
\hline $\begin{array}{l}\text { Iodine value (IV) "mg } \\
\text { iodine/100g oil" }\end{array}$ & & & & $82.72 \pm 0.71$ & $83.52 \pm 0.58$ & $113.30 \pm 1.04$ & & & \\
\hline Refraction Index (RI) & & & & $1.4778 \pm 0.0009$ & $1.4837 \pm 0.0070$ & $1.4825 \pm 0.0008$ & & & \\
\hline
\end{tabular}

SAFA: saturated fatty acids; MUFA: monounsaturated fatty acids; PUFA: polyunsaturated fatty acids; tr: traces; -: not determined.

NL: neutral Lipids; PL: Polar Lipids; TL: Total Lipids; A: Adrar; B: Biskra; O: Ouargla

content of polar lipids ranged from weak to moderate values (3.9-13.85\%); the lowest value was recorded for the region of Adrar. As a result, L. alba seed oils exhibited high amounts of neutral lipids (85.82-93.08\%) when chloroform/methanol solvent was employed.
Moreover, the difference in interaction between solvent and solutes, caused by both solvent polarities and their boiling temperature, may contribute to the extraction efficiency and yield, as well as the composition of the extracted oils [45]. 
Table 3. Individual tocopherols content and their relative composition in Lawsonia alba seed oils (n-hexane).

\begin{tabular}{|c|c|c|c|c|c|c|}
\hline \multirow{2}{*}{ Tocopherols } & \multicolumn{2}{|c|}{ Biskra } & \multicolumn{2}{|c|}{ Ouargla } & \multicolumn{2}{c|}{ Adrar } \\
\cline { 2 - 7 } & $\begin{array}{c}\text { Content } \\
(\mathbf{m g} / \mathbf{1 0 0} \mathbf{g})\end{array}$ & $\begin{array}{c}\text { Composition } \\
(\boldsymbol{\%})\end{array}$ & $\begin{array}{c}\text { Content } \\
(\mathbf{m g} / \mathbf{1 0 0} \mathbf{g})\end{array}$ & $\begin{array}{c}\text { Composition } \\
(\boldsymbol{\%})\end{array}$ & $\begin{array}{c}\text { Content } \\
(\mathbf{m g} / \mathbf{1 0 0} \mathbf{g})\end{array}$ & $\begin{array}{c}\text { Composition } \\
(\boldsymbol{\%})\end{array}$ \\
\hline \hline$\alpha$-tocopherol & $\mathrm{nd}$ & $\mathrm{nd}$ & 0.00 & 0.00 & $28.46 \pm 1.34$ & $7.10 \pm 0.09$ \\
\hline$\beta$-tocopherol & $\mathrm{nd}$ & $\mathrm{nd}$ & $17.60 \pm 0.15$ & $2.34 \pm 0.07$ & $15.59 \pm 0.13$ & $3.89 \pm 0.02$ \\
\hline$\gamma$-tocopherol & $\mathrm{nd}$ & $\mathrm{nd}$ & $441.77 \pm 1.81$ & $58.71 \pm 0.92$ & $207.64 \pm 1.11$ & $51.77 \pm 0.89$ \\
\hline$\delta$-tocopherol & $\mathrm{nd}$ & $\mathrm{nd}$ & $293.13 \pm 1.03$ & $38.95 \pm 0.06$ & $149.40 \pm 0.89$ & $37.25 \pm 0.07$ \\
\hline & & & & & \\
\hline Total & $\mathrm{nd}$ & $\mathrm{nd}$ & 752.5 & 100.00 & 401.09 & 100.00 \\
\hline
\end{tabular}

nd: not determined.

The total Fatty Acid (FA) composition of the oils obtained in this study was determined by GC, and is shown in Tables 1 and 2. The first table presents the FA compositions of lipid fractions obtained by $n$-hexane solvent; while the second table gathers the lipids obtained by chloroform/methanol solvent (total lipids fraction and both neutral and polar sub-extractions or fractionations).

The FA profile is a main determinant of the oil quality. Fatty acid analysis has shown that the seed oils studied contained twelve fatty acids: Five were saturated FAs (SFAs), four were monounsaturated FAs (MUFAs) and three were polyunsaturated FAs (PUFAs) with 14 to 20 carbons.

The major fatty acids identified in all tested samples were the linoleic acid (18:2) (45.10-74.39\%), palmitic acid (16:0) (8.84-21.52\%), oleic acid (18:1) (8.48-17.19\%), stearic acid (C18:0) (3.29-8.01\%), arachidic acid (C20:0) (1.39-2.48\%) and eicosapentaenoic acid (C20:5) (0.47-2.43\%) (Tables 1 and 2). The linoleic, palmitic and oleic acids accounted for more than $83 \%$ of the total fatty acid content. Moreover, FA $(14: 0,16: 1,17: 0,17: 1,18: 3,20: 1)$ were absent or detected at low percentages (0.03-1.22\%) in these lipids. The results of fatty acids profile of the oils are similar to those reported previously for Lawsonia alba seed oils [20-24], and Lawsonia inermis seed oils [35]. Furthermore, the three main fatty acid components were the same as those of Pistacia atlantica fruits (whose oils were considered as dietary nutriment) [46].

All oils had high amounts of the Polyunsaturated Fatty Acid (PUFA) that primarily was linoleic acid. The polyunsaturation was found to be $48.22-75.06 \%$ as shown in Tables $\mathbf{1}$ and $\mathbf{2}$. The ratio of unsaturated fatty acids to saturated fatty acids was mainly higher in the oils than in the polar lipid fractions.

The results suggested that L. alba oil is a good source of unsaturated fatty acids; it means that it should exhibit high antioxidant activity. Let's remind that unsaturated fatty acids are very important compounds for the stability of oils, because of the chemical reactions occurring at the double bonds [45]. The high unsaturation degree of the oils allows them to be oxidized easily when used at high temperatures. For example, linoleic acid oxidizes approximately 50 times faster than oleic acid [47].

\section{Tocopherol Contents and Compositions of L. alba Seed Oils}

In spite of the nutritional importance of tocopherols [48, 49], their content and composition in L. alba seed oils remain unknown. The quantification of tocopherols by liquid chromatography was based on an external standard method using $\alpha$-tocopherol. The results are expressed as $\mathrm{mg}$ of $\alpha$ tocopherol equivalents per $100 \mathrm{~g}$ of oil. Results are presented in Table 3, which shows clearly that the seed oils are rich in tocopherols, and especially for $\gamma$ - and $\delta$ - tocopherols. For the region of Biskra no presence of tocopherols was detected. However, the total tocopherol content of the Ouargla region $(752.5 \mathrm{mg} / 100 \mathrm{~g})$ was found to almost twice as big as the one of the Adrar region (401.09 $\mathrm{mg} / 100 \mathrm{~g}$ ). In addition, the contents of both $\gamma$ - and $\delta$ - tocopherols were twice as high as the one of the Adrar region; although the $\beta$-tocopherol contents in both regions were similar $(17.60 \%$ and $15.59 \%)$. Furthermore, the compositions of $\beta$ - and $\delta$ - tocopherols for these two last regions were very close to each other: $38.9 \%$ and $37.25 \%$, respectively. The percentage of $\gamma$-tocopherol in the Ouargla region $(58.71 \%)$ was slightly higher than the Adrar region $(51.77 \%)$. Conversely, and unlike the Adrar region the $\alpha$-tocopherol was absent in the Ouargla region. It was noted that the sum of $\alpha$ - and $\gamma$-tocopherols percentages were practically the same for the two studied regions (Adrar: $58.71 \%$, Ouargla: $58.87 \%$ ).

\section{Antioxidant Activities}

\section{Free Radical Scavenging Activity}

The antioxidant activities of $L$. alba seed oils were determined using the DPPH free radical assay. The DPPH is a stable free radical which has been widely used to evaluate the radical scavenging ability of antioxidants [50]. DPPH radical scavenging assays are based on the transfer of electrons from a donor molecule to the corresponding radical. The reduction capacity of DPPH radicals was determined by the decrease of absorbance at $517 \mathrm{~nm}$. This activity can be evaluated by the determination of the $\mathrm{IC}_{50}$ values. Low $\mathrm{IC}_{50}$ value indicates strong antioxidant activity in a tested sample [51]. The $\mathrm{IC}_{50}$ value can be defined as the amount of antioxidant necessary to decrease the initial DPPH 
Table 4. Antioxidant activities of the lipids extracts of $L$. alba seeds.

\begin{tabular}{|c|c|c|c|c|c|c|c|c|c|}
\hline \multicolumn{2}{|c|}{ Region } & \multicolumn{2}{|c|}{ Biskra } & \multicolumn{2}{|c|}{ Ouargla } & \multicolumn{2}{|c|}{ Adrar } & & \\
\hline \multicolumn{2}{|c|}{ Antioxidant assay } & $\begin{array}{c}\text { DPPH } \\
\mathrm{IC}_{\mathrm{s0}} \\
(\mathrm{mg} / \mathrm{mL})\end{array}$ & $\begin{array}{c}\text { PPM VEEAC } \\
(\mathbf{m g} / \mathbf{m L})\end{array}$ & $\begin{array}{c}\text { DPPH } \\
\text { IC }_{50}(\mathrm{mg} / \mathrm{mL})\end{array}$ & $\begin{array}{c}\text { PPM VEEAC } \\
(\mathbf{m g} / \mathbf{m L})\end{array}$ & $\begin{array}{c}\text { DPPH } \\
\text { IC }_{50} \\
(\mathrm{mg} / \mathrm{mL})\end{array}$ & $\begin{array}{c}\text { PPM VEEAC } \\
(\mathrm{mg} / \mathrm{mL})\end{array}$ & $\begin{array}{c}\text { DPPH } \\
I_{50}(\mathrm{mg} / \mathrm{mL})\end{array}$ & $\begin{array}{c}\text { PPM } \\
\text { VEEAC } \\
(\mathbf{m g} / \mathbf{m L})\end{array}$ \\
\hline \multicolumn{2}{|c|}{$n$-hexane extracts } & $>31.96$ & $0.21 \pm 0.01$ & $5.31 \pm 0.31$ & $0.14 \pm 0.01$ & $16.54 \pm 0.20$ & $0.16 \pm 0.01$ & - & - \\
\hline \multirow{3}{*}{$\begin{array}{c}\mathrm{CHCl}_{3} / \mathrm{MeOH} \\
\text { extracts }\end{array}$} & Total lipids & $0.56 \pm 0.01$ & $0.27 \pm 0.01$ & $0.38 \pm 0.02$ & $0.20 \pm 0.01$ & $2.21 \pm 0.12$ & $0.23 \pm 0.01$ & - & - \\
\hline & Neutral lipids & $1.94 \pm 0.04$ & $0.23 \pm 0.01$ & $1.91 \pm 0.05$ & $0.20 \pm 0.01$ & $5.3 \pm 0.30$ & $0.27 \pm 0.01$ & - & - \\
\hline & Polar lipids & $0.11 \pm 0.01$ & $0.57 \pm 0.01$ & $0.12 \pm 0.01$ & $0.41 \pm 0.03$ & $0.51 \pm 0.05$ & $0.52 \pm 0.02$ & - & - \\
\hline \multirow{3}{*}{ Standards } & Vit. $\mathrm{E}$ & - & - & - & - & - & - & $0.02 \pm 0.01$ & - \\
\hline & Vit. C & - & - & - & - & - & - & $0.0096 \pm 0.0005$ & $0.95 \pm 0.03$ \\
\hline & BHA & - & - & - & - & - & - & $0.0086 \pm 0.0006$ & - \\
\hline
\end{tabular}

concentration by $50 \%$ [52]. Vitamin C, BHA, BHT and vitamin $\mathrm{E}$ were used as standards.

According to Table $4, \mathrm{IC}_{50}$ values of the $\mathrm{DPPH}^{\bullet}$ radical scavenging activity ranged from 0.11 to $31.96 \mathrm{mg} / \mathrm{mL}$ for the twelve oils extracts. PLB (Biskra), PLO (Ouargla), TLO (Ouargla), PLA (Adrar) and TLB (Biskra) oils extracts gave good values of the $\mathrm{IC}_{50}: 0.11,0.12,0.38,0.51$ and 0.56 $\mathrm{mg} / \mathrm{mL}$ respectively, while the $\mathrm{IC}_{50}$ values of the standards BHA, ascorbic acid, Vitamin E and BHT, which showed an excellent scavenging activity, were 0.0086, 0.0096, 0.0188 and $0.1 \mathrm{mg} / \mathrm{mL}$ respectively. NLB ( $n$-hexane extract) did not show any antioxidant activity (very weak value).

Referring to the results of DPPH assay (Table 4), the lowest antioxidant activities were detected for NL ( $n$-hexane extract) fractions, whereas the highest antioxidant activities were detected for Polar Lipids (PL) fractions in all the samples. Also Total Lipids (TL) fractions appeared to be more effective scavengers against DPPH radical than NL (Chloroform/MeOH extract) fractions. Finally it seemed that the region of collection did not affect strongly the antioxidant activities of the tested fractions.

In the literature, the inhibition of DPPH radical scavenging by plant oils can be attributed to the unsaturated fatty acids (PUFA), phospholipids, total phytosterols, total tocopherols, carotenoids and phenolics [47, 53, 54]. Therefore, the antioxidant activities of the Lawsonia alba oils can be attributed to the unsaturated fatty acids, tocopherols and polar lipid compound present in the samples.

\section{Antioxidant Capacity by Phosphomolybdenum Method "Total Antioxidant Activity"}

The phosphomolybdenum PPM is a method based on the reduction of Mo (VI) to Mo (V) by the antioxidant compound; this reaction is accompanied by the appearance of a green colour phosphate/Mo (V) (phosphomolybdenum) complex with a maximal absorption at $695 \mathrm{~nm}$ and acidic $\mathrm{pH}$ [28]. A higher absorbance indicates a higher total antioxidant capacity [51].

Total antioxidant activities of the lipid extracts, expressed as VEEAC, are shown in Table 4. Ascorbic acid
"Vitamin C" (VC), which was used as a positive control, presented the highest antioxidant capacity from all tested samples (VEEAC $=0.95 \mathrm{mg} / \mathrm{mL}$ ). In lipids extracts, total antioxidant activities were found to be high in PLB (VEEAC $=0.57 \mathrm{mg} / \mathrm{mL})$ followed by PLA $(0.52 \mathrm{mg} / \mathrm{mL})$, and PLO $(0.41 \mathrm{mg} / \mathrm{mL})$. For these PLB and PLA fractions, the antioxidant power was almost 2 times less active than vitamin C while PLO was more than 2 times less active than vitamin $\mathrm{C}$. On the other hand, the rest of the fractions exhibited lower antioxidant activities with very close values of VEEAC and ranging from 0.16 to $0.27 \mathrm{mg} / \mathrm{mL}$. This range can be roughly approximated to a mean value of 0.2 $\mathrm{mg} / \mathrm{mL}$, which means that these extracts exhibited 5 times lower activities than vitamin E. Moreover, and no matter the region of collection, it was found that strong activities of the oils were mostly decreasing in the following order: PL>NL (chloroform/methanol) $>\mathrm{TL}>\mathrm{NL}$ ( $n$-hexane). These results were expected, since most known strong antioxidant chemicals include polar functions responsible for their activities.

Correlation between total tocopherol contents and antioxidant activities using DPPH and phosphomolybdenum assays were investigated. After a close examination of the results of Table 4 , it was noticed that the antioxidant activity powers of the seed oils (NL obtained by $n$-hexane extracts) from the three investigated regions were decreasing in the following order Ouargla > Adrar > Biskra i.e. (DPPH: $5.31>$ $16.54>31.96 \mathrm{mg} / \mathrm{mL}$; Phosphomolybdenum: $0.14>0.16>$ $0.21 \mathrm{mg} / \mathrm{mL}$ ). This decline in activities may be attributed to the total contents of tocopherols which were also decreasing in the same order for the same regions. In other words, a direct correlation between total tocopherol contents and antioxidant powers was observed.

\section{Statistical Analysis Using Hierarchy Ascendant Classification Method (HAC)}

In order to highlight the difference in the contents of the main fatty acids FAs ( $n$-hexane extracts) of the seeds of Lawsonia alba (collected from different regions: Adrar, Biskra, Ouargla) with some chosen common seed plants (data provided from the literature [31, 55-58]), we have 


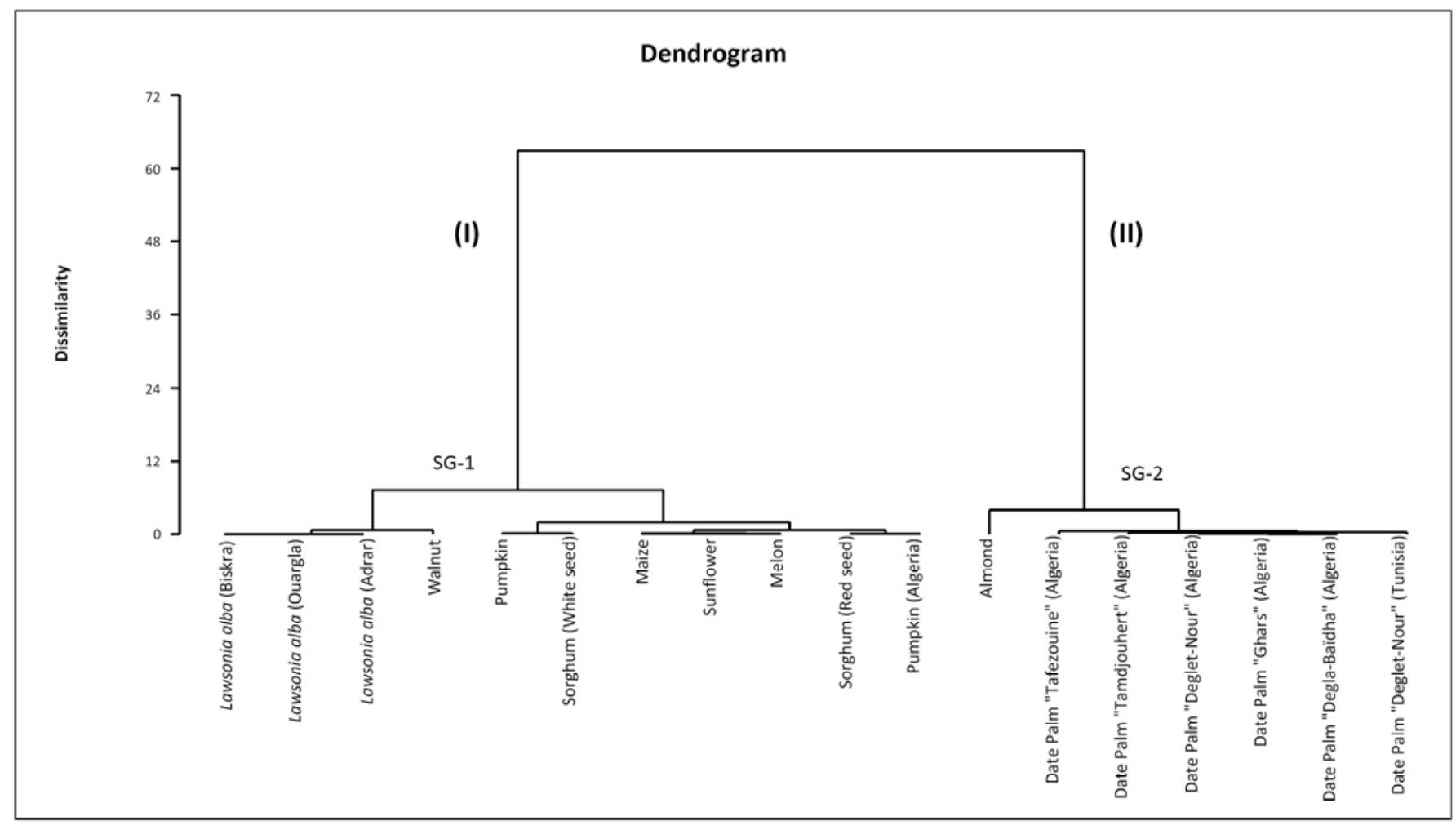

Fig. (2). Dendrogram obtained from a cluster analysis of the fatty acids obtained from different seed oils of Algerian cultivars of Lawsonia alba and a selection of seed oils of different edible plants. Samples are clustered using Ward's technique with a Euclidean distance measure.

adopted the method of cluster analysis, using Ward's technique; 14 fatty acids representing the main identified compounds in these plants (18 individuals) were employed. The results show the existence of two principal clusters (I and II) within the fatty acids of the individuals of the investigated plants (Fig. 2). First cluster (I) includes the following seed plants: Lawsonia alba, Walnut, Pumpkin, Sorghum, Maize, Sunflower, Melon while the second cluster (II) is composed of only Date palm varieties and Almond. The last cluster shows that the fatty acids contents of the Date palm seed varieties have a similar pattern in comparison with Almond; indeed this group is characterized by roughly close contents of $\mathrm{C}_{16: 1}, \mathrm{C}_{17: 0}, \mathrm{C}_{17: 1}, \mathrm{C}_{18: 0}, \mathrm{C}_{18: 1}, \mathrm{C}_{18: 3}, \mathrm{C}_{20: 0}, \mathrm{C}_{20: 1}, \mathrm{C}_{20: 5}$. The major difference between them lies in the moderate/high content of $\mathrm{C}_{12: 0}$ and $\mathrm{C}_{14: 0}(9.84-11.6 \%$ and $17.8-28.4 \%$, respectively) for the Date palm varieties versus their negligible contents for the Almond $\left(\mathrm{C}_{12: 0}: 0 \%, \mathrm{C}_{14: 0}: 0.03 \%\right)$. The data examination of the cluster (I) revealed that this group is characterized by high contents of $\mathrm{C}_{16: 0}, \mathrm{C}_{18: 1}$ and $\mathrm{C}_{18: 2}$ (mean \pm sd: $10.47 \pm 6.06 \%, 25.67 \pm 16.94 \%$ and $57.23 \pm 18.72 \%$, respectively) and low contents of $\mathrm{C}_{10: 0}, \mathrm{C}_{12: 0}, \mathrm{C}_{14: 0}, \mathrm{C}_{16: 1}$, $\mathrm{C}_{17: 0}, \mathrm{C}_{17: 1}, \mathrm{C}_{18: 0}, \mathrm{C}_{18: 3}, \mathrm{C}_{20: 0}, \mathrm{C}_{20: 1}, \mathrm{C}_{20: 5}$ (<5.3\%). Let's remind that the first cluster could be separated into two close sub groups SG-1 and SG-2. The SG-1 showed that the fatty acids profiles of Lawsonia alba samples are pretty similar to Walnut; but the tiny difference between them is due to a significant content of $\mathrm{C}_{18: 3}(11.37 \%)$ for Walnut when compared to Lawsonia alba samples where it was insignificant (0.11-0.37\%). As a general conclusion, the HAC analysis revealed that the studied seeds have very similar fatty acids profiles to most common considered edible plants.

\section{CONCLUSION}

In conclusion, it was found that the seed oils coming from three different regions in Algeria (Adrar, Ouargla, and Biskra) presented practically the same chemical compositions of fatty acids compound; and despite the fact that there was no significant impact of the regions of collection on the values of the antioxidant activities in terms of both DPPH and Phosphomolebdenum assays this current report reveals the richness of the Lawsonia alba seeds in tocopherols, which in fact is studied for the first time.

The physico-chemical characterization and the fatty acid profile suggest the possible application of the oils in the industry of liquid soaps and hair shampoo. The results suggested that Lawsonia alba oils are a good source of unsaturated fatty acids with good antioxidant activity in terms of Phosphomolybdenum assay (total antioxidant power).

On the other hand, cluster analysis revealed that fatty acid composition of the seed oils of Lawsonia alba was very close to those of Walnut.

\section{CONFLICT OF INTEREST}

The author(s) confirm that this article content has no conflict of interest.

\section{ACKNOWLEDGEMENTS}

Declared none. 


\section{REFERENCES}

[1] Bakkali AT, Jaziri M, Foriers A, Vander Heyden Y, Vanhaelen M, Homes J. Lawsone accumulation in normal and transformed cultures of henna, Lawsonia inermis. Plant Cell Tiss Org Cult 1997; 51(2): 83-7.

[2] Chaudhary G, Goyal S, Poonia P. Lawsonia inermis Linnaeus: A phytopharmacological review. Int J Pharm Sci Drug Res 2010; 2(2): 91-8.

[3] Goswami M, Kulshreshtha M, Rao CV, Yadav S, Yadav S. Antiulcer potential of Lawsonia inermis L. Leaves against gastric ulcers in rats. J Appl Pharm Sci 2011; 1(2): 69-72.

[4] Makhija IK, Dhananjaya DR, Kumar VS, et al. Lawsonia inermisFrom traditional use to scientific assessment. Afr J Pharm Pharmacol 2011; 2(1): 145-65.

[5] Uddin N, Siddiqui BS, Begum S, et al. Bioactive flavonoids from the leaves of Lawsonia alba (Henna). Phytochem Lett 2011; 4(4): 454-8.

[6] Ghosh A, Das BK, Roy A, Mandal B, Chandra G. Antibacterial activity of some medicinal plant extracts. J Nat Med 2008; 62(2): 259-62.

[7] Chaudhury A, Duhan P, Poonia A, Kajla S. Efficient method for micropropagation of Lawsonia inermis. World Congress on Biotechnology; 21-23 March 2011.

[8] Singh VK, Pandey DK. Fungitoxic studies on bark extract of Lawsonia inermis against ringworm fungi. Hindustan Antibiot Bull 1989; 31(1-2): 32 .

[9] Okpekon T, Yolou S, Gleye C, et al. Antiparasitic activities of medicinal plants used in Ivory Coast. J Ethnopharmacol 2004; 90(1): 91-7.

[10] Khan MMAA, Jain DC, Bhakuni RS, Zaim M, Thakur RS. Occurrence of some antiviral sterols in Artemisia аппиа. Plant Sci 1991; 75(2): 161-5.

[11] Endrini S. Comparing of the cytotoxicity properties and mechanism of Lawsonia inermis and Strobilanthes crispus extract against several eancer cell lines. J Med Sci 2007; 7(7): 1098-102.

[12] Abdillah S, Budiady I, Winarno H. Hypoglycaemic and antihyperlipidemic effects of henna leaves extract (Lawsonia inermis Linn) on alloxan induced diabetic mice. Jordan J Pharm Sci 2008; 1(2): 126-31.

[13] Syamsudin I, Winarno H. The effect of Inai (Lawsonia inermis Linn) leaves extract on blood sugar level: An experimental study. Res J Pharmacol 2008; 2(2): 20-3.

[14] Hosein HKM, Zinab D. Phenolic compounds and antioxidant activity of henna leaves extracts (Lawsonia inermis). World J Dairy Food Sci 2007; 2(1): 38-41.

[15] Rahmat A. Anticarcinogenic properties and antioxidant activity of henna (Lawsonia inermis). J Med Sci 2002; 2(4): 194-7.

[16] Sharma VK. Tuberculostatic activity of henna (Lawsonia inermis Linn.). Tubercle 1990; 71(4): 293-5.

[17] Gupta S, Ali M, Pillai KK, Sarwar Alam M. Evaluation of antiinflammatory activity of some constituents of Lawsonia inermis. Fitoterapia 1993; 64(4): 365-6.

[18] Munshi SR, Shetye TA, Nair RK. Antifertility activity of three indigenous plant preparations. Planta Med 1977; 31(1): 73-5.

[19] Nayak BS, Isitor G, Davis EM, Pillai GK. The evidence based wound healing activity of Lawsonia inermis Linn. Phytother Res 2007; 21(9): 827-31.

[20] Aggarwal S, Dhingra D. Chemical examination of the seed oil of Lawsonia alba. Indian Oil Soap J 1959; 25: 145.

[21] Ansari A, Osman S, Subbaram M. Component acids of minor seed oils. J Oil Technol Assoc India 1975; 7(1): 26-7.

[22] Raie M, Iqbal S, Khan S. Physico-chemical characterization of Lawsonia alba oil of the family myrtaceae. Pak J Sci Ind Res 1982; 25(4): 112.

[23] Ahmad M, Rauf A, Osman S. Physio-chemical analysis of seven seed oils. J Oil Technol Assoc India 1989; 21(3): 46-7.

[24] Datta B, Ahmed M, Banoo R. Determination of some characteristics and fatty acid composition of the seed oil of Lawsonia alba. $\mathbf{J}$ Bangladesh Acad Sci 1992; 16: 263-4.

[25] Folch J, Lees M, Sloane-Stanley GH. A simple method for the isolation and purification of total lipids from animal tissues. J Biol Chem 1957; 226(1): 497-509.

[26] French Association for Standardization (Author). Corps gras, graines oléagineuses et produits dérivés, 3rd ed. AFNOR: Paris 1984; pp. 459.
[27] Molyneux P. The use of the stable free radical diphenylpicrylhydrazyl (DPPH) for estimating antioxidant activity. Songklanakarin J Sci Technol 2004; 26(2): 211-9.

[28] Prieto P, Pineda M, Aguilar M. Spectrophotometric quantitation of antioxidant capacity through the formation of a phosphomolybdenum complex: specific application to the determination of vitamin E. Anal Biochem 1999; 269(2): 337-41.

[29] Charef M, Yousfi M, Saidi M, Stocker P. Determination of the fatty acid composition of acorn (Quercus), Pistacia lentiscus seeds growing in Algeria. J Am Oil Chem Soc 2008; 85(10): 921-4.

[30] León-Camacho M, Viera-Alcaide I, Vicario IM. Acorn (Quercus spp.) fruit lipids: Saponifiable and unsaponifiable fractions: A detailed study. J Am Oil Chem Soc 2004; 81(5): 447-53.

[31] Hadbaoui Z, Djeridane A, Yousfi M, Saidi M, Nadjemi B. Fatty acid, tocopherol composition and the antioxidant activity of the lipid extract from the sorghum grains growing in Algeria. Med J Nutrition Metab 2010; 3(3): 215-20.

[32] Hamia C, Gourine N, Boussoussa H, Saidi M, Gaydou EM, Yousfi M. Chemical composition and antioxidant activity of the essential oil and fatty acids of the flowers of Rhanterium adpressum. Nat Prod Commun 2013; 8(8): 1171-4.

[33] Sonntag NOV. Composition and characteristics of individual fats and oils. In: Swern D, Ed. Bailey's industrial oil and fat products. John Wiley \& Sons, NY 1979; pp. 289-478.

[34] Atal CK, Kapoor KK, Siddiqui HH. Studies on Indian seed oils. Part I. Preliminary screening of linoleic acid rich oils. Indian J Pharm 1964; 26: 163-4.

[35] Graham SA, Kleiman R. Seed lipids of the Lythraceae. Biochem Syst Ecol 1987; 15(4): 433-9.

[36] Nehdi IA, Sbihi H, Tan CP, Zarrouk H, Khalil MI, Al-Resayes SI. Characteristics, composition and thermal stability of Acacia senegal (L.) Willd. seed oil. Ind Crops Prod 2012; 36(1): 54-8.

[37] Cerchiara T, Chidichimo G, Ragusa MI, Belsito EL, Liguori A, Arioli A. Characterization and utilization of Spanish Broom (Spartium junceum L.) seed oil. Ind Crops Prod 2010; 31(2): 423-6.

[38] Sam SM, Akonye LA, Mensah SI, Esenowo GJ. Extraction and classification of lipids from seeds of persea Americana miller and Chrysophyllum albidum g. Don. Scientia Africana 2008; 7(2): 35-8.

[39] Therios IN. Olives. Atherton J, Ed. CAB International: UK 2009; pp. 409.

[40] Onyeike EN, Acheru GN. Chemical composition of selected Nigerian oil seeds and physicochemical properties of the oil extracts. Food Chem 2002; 77(4): 431-7.

[41] Boran G, Karaçam H, Boran M. Changes in the quality of fish oils due to storage temperature and time. Food Chem 2006; 98(4): 6938.

[42] Nehdi I, Omri S, Khalil MI, Al-Resayes SI. Characteristics and chemical composition of date palm (Phoenix canariensis) seeds and seed oil. Ind Crops Prod 2010; 32(3): 360-5.

[43] Nehdi I. Characteristics, chemical composition and utilisation of Albizia julibrissin seed oil. Ind Crops Prod 2011; 33(1): 30-4.

[44] Ku CS, Mun SP. Characterization of seed oils from fresh Bokbunja (Rubus coreanus Miq.) and wine processing waste. Bioresour Technol 2008; 99(8): 2852-6.

[45] Wu H, Shi J, Xue S, et al. Essential oil extracted from peach (Prunus persica) kernel and its physicochemical and antioxidant properties. LWT-Food Sci Technol 2011; 44(10): 2032-9.

[46] Guenane H, Bombarda I, Didi-Ould-Elhadj M, Yousfi M. Effect of maturation degree on composition of fatty acids and tocopherols of fruit oil from Pistacia atlantica growing wild in Algeria. Nat Prod Commun 2015; 10(10): 1723-8.

[47] Luzia DMM, Jorge N. Bioactive substance contents and antioxidant capacity of the lipid fraction of Annona crassiflora Mart. seeds. Ind Crops Prod 2013; 42: 231-5.

[48] Kamal-Eldin A, Appelqvist L-Å. The chemistry and antioxidant properties of tocopherols and tocotrienols. Lipids 1996; 31(7): 671701.

[49] Hussain N, Irshad F, Jabeen Z, Shamsi IH, Li Z, Jiang L. Biosynthesis, structural, and functional attributes of tocopherols in planta; past, present, and future perspectives. J Agric Food Chem 2013; 61(26): 6137-49.

[50] Murugan R, Parimelazhagan T. Comparative evaluation of different extraction methods for antioxidant and anti-inflammatory properties from Osbeckia parvifolia Arn. An in vitro approach. J King Saud Uni Sci 2014; 26(4): 267-75. 
[51] Loo AY, Jain K, Darah I. Antioxidant activity of compounds isolated from the pyroligneous acid, Rhizophora apiculata. Food Chem 2008; 107(3): 1151-60.

[52] Antolovich M, Prenzler PD, Patsalides E, McDonald S, Robards K. Methods for testing antioxidant activity. Analyst 2002; 127(1): 183-98.

[53] Gai Q-Y, Jiao J, Mu P-S, et al. Microwave-assisted aqueous enzymatic extraction of oil from Isatis indigotica seeds and its evaluation of physicochemical properties, fatty acid compositions and antioxidant activities. Ind Crops Prod 2013; 45: 303-11.

[54] Jiao J, Li Z-G, Gai Q-Y, et al. Microwave-assisted aqueous enzymatic extraction of oil from pumpkin seeds and evaluation of its physicochemical properties, fatty acid compositions and antioxidant activities. Food Chem 2014; 147: 17-24.
[55] Boukouada M, Ghiaba Z, Gourine N, Bombarda I, Saidi M, Yousfi M. chemical composition and antioxidant activity of seed oil of two Algerian date palm cultivars (Phoenix dactylifera). Nat Prod Commun 2014; 9(12): 1777-80.

[56] Sabudak T. Fatty acid composition of seed and leaf oils of Pumpkin, Walnut, Almond, Maize, Sunflower and Melon. Chem Nat Compd 2007; 43(4): 465-7.

[57] Besbes S, Blecker C, Deroanne C, Drira N-E, Attia H. Date seeds: chemical composition and characteristic profiles of the lipid fraction. Food Chem 2004; 84(4): 577-84

[58] Benalia M, Djeridane A, Gourine N, Nia S, Ajandouz E, Yousfi M. Fatty acid profile, tocopherols content and antioxidant activity of algerian pumpkin seeds oil (Cucurbita pepo L). Med J Nutrition Metab 2015; 8(1): 9-25. 